\title{
IbM ALAT PERAGA MATEMATIKA SD DARI PENGOLAHAN SAMPAH KARET SANDAL DI KECAMATAN KLANGENAN
}

\author{
1) Widia Nur Jannah, ${ }^{2)}$ Desy Lusiyana, ${ }^{3)}$ Susilawati \\ 1), 2), 3)Fakultas Keguruan dan Ilmu Pendidikan, Universitas Muhammadiyah Cirebon \\ 1) email : widianurjannah87@gmail.com
}

\begin{abstract}
Klangenan district is one of industrial areas which is well-known as rubber slippers provider in Cirebon. The slipper scraps are not optimized yet hence they can be made for tools to learn especially for mathematic tools in elementary students. The objective of this research is to improve elementary teachers' ability concerning the use of mathematic tools which are made from rubber waste of slippers. This activity is initiated by socializing information regarding the benefits of the tools, training to conduct mathematical tools made of inorganic rubber scraps of slippers, and assisting teachers of elementary school concerning the implementation of mathematical tools in the classroom. Counseling and training assistance were delivered to teachers at Jemaras Lor Elementary School 1 and 2 from educational service, Technical Initiating Unit (UPT) of Klangenan District, Head of Research Institute and Community Service (LPPM) of Muhammadiyah University of Cirebon, and all the lecturers of Faculty of Teacher Training and Education, Muhammadiyah University of Cirebon. The first results is increasing teachers' knowledge and skill concerning teaching instruments and teaching tools. Second is teachers are creative to create and produce 10 economic mathematic tools. The students are more interested in learning and average final test is above 70.
\end{abstract}

Keywords: mathematic tools, rubber waste of slippers

\section{PENDAHULUAN}

Kecamatan Kelangenan merupakan wilayah sentra industri produksi sandal karet terbanyak yaitu berada di desa Jemaras Lor. Semakin melimpahnya produksi sandal berbanding lurus dengan jumlah sampah karet dari sisa pembuatan sandal. Sejalan dengan banyaknya sampah karet sandal yang ada di desa Jemaras, Hadi (2005) mengatakan bahwa sampah akan menjadi beban bumi, artinya ada resiko-resiko yang akan ditimbulkannya.

Sampah adalah sisa kegiatan sehari-hari manusia dan/atau proses alam yang berbentuk padat. Sampah merupakan material sisa yang tidak diinginkan setelah berakhirnya suatu proses (UU No.18 tahun 2008). Sampah juga merupakan konsep buatan manusia, dalam proses-proses alam tidak ada sampah, yang ada hanya produk-produk yang tak bergerak. (Kementerian Lingkungan Hidup, 2008).

Hasil observasi pada tanggal 2 Mei 2016 menunjukkan bahwa pemanfaatan limbah sandal selama ini hanya digunakan atau dimanfaatkan untuk permainan anak-anak, Namun pada dasarnya pemanfaatan limbah sandal bisa juga digunakan untuk bahan dasar alat peraga, manfaat secara tidak langsung dapat mengurangi pencemaran lingkungan. Selain itu pemanfaatan limbah sandal sebagai alat peraga matematika dapat membantu guru dalam mengembangkan kreativitasnya membuat alat peraga yang ekonomis.

Sejalan dengan adanya penumpukan limbah karet sandal dan pemanfaatannya dapat digunakan sebagai bahan dasar alat 
peraga, maka berdasarkan hasil observasi di SD Negeri 1 dan 2 Jemaras Lor memang terlihat beberapa kelas yang tidak memiliki alat peraga matematika khususnya di kelas 2 dan 3.

Hasil wawancara dengan beberapa guru dan kepala sekolah yang dilakukan pada tanggal 3 Mei 2016 diperoleh informasi bahwa, pembelajaran matematika dilaksanakan selama ini jarang mengunakan media atau alat peraga yang inovatif. Guru masih menggunakan metode ceramah, sehingga siswa hanya mendengarkan guru menjelaskan konsep dan latihan tanpa didukung oleh alat peraga. Siswa cenderung menghafal konsep atau prosedur matematik dan belajar matematika lebih banyak secara mekanistik. Hal ini berdampak pada rendahnya prestasi belajar matematika siswa dan pembelajaran matematika berlangsung dengan membosankan. Pelajaran matematika diterapkan kepada anak SD harus secara bertahap dan membutuhkan keterampilan. Menurut Priatna, et al. (2007 : 37) "Dasar pemikiran belajar matematika adalah memahami matematika secara efektif dengan melibatkan siswa dalam proses belajar aktif". Siswa harus cenderung yang lebih aktif dalam pembelajaran matematika.

Materi di dalam pembelajaran matematika, konsep itu dipahami bukan dihafalkan. Menurut Suwangsih (2006:3) konsep matematika didapat karena proses berfikir, karena itu logika adalah dasar terbentuknya matematika. Pembelajaran matematika akan bermakna bagi siswa apabila konsepnya dipahami dan kemudian siswa akan mudah menemukan aplikasi dari konsep yang diajarkan di dalam kehidupannya.

Oleh karena itu, harus ada media atau alat peraga yang membantu siswa memahami konsep. Menurut Suwardi, dkk (2014) keberhasilan proses pembelajaran diperlukan adanya media atau alat peraga yang dapat mempertinggi proses dan hasil belajar yang berkenaan dengan taraf berpikir siswa. Contohnya dalam materi pecahan, siswa harus memahami konsep pecahan. Pemahaman siswa dalam pecahan bukan dari penjelasan guru tetapi diperoleh dari pehaman siswa tentang pecahan yang selalu berkaitan dengan pembilang, penyebut dan pemahaman tentang "berapa bagian". Hal ini berkaitan dengan pehaman siswa yang diperoleh dengan memanipulasi langsung benda-benda konkrit.

Melihat permasalahan tersebut, dapat diambil kesimpulan bahwa beberapa sekolah dasar yang berada di Kecamatan Klangenan khususnya di Desa Jemaras Lor membutuhkan media atau alat peraga matematika yang inovatif dan ekonomis, guru dan kepala sekolah membutuhkan wawasan tentang pentingnya alat peraga, serta membutuhkan beberapa guru yang kreatif dalam pembuatan alat peraga.

Berdasarkan analisis situasi dapat teridentifikasi beberapa permasalahan yang dihadapai oleh mitra, yaitu: (1) Hasil belajar matematika siswa masih dibawah KKM yang ditetapkan oleh sekolah, yaitu 7,0 untuk mata pelajaran matematika (2) Pengetahuan para guru dalam merancang dan menggunakan alat peraga matematika yang inovatif sangat kurang. Selain itu, dari pihak sekolah juga tidak menyediakan media ataupun alat-alat peraga matematika yang dapat digunakan oleh guru dalam melaksanakan pembelajaran (3) Kurangnya informasi pembuatan alat peraga matematika dari limbah anorganik (4) Kurangnya inovasi dan daya kreativitas guru dalam memanfaatkan limbah (5) Kurangnya pemahaman pembinaan dari dinas pendidikan setempat untuk melatih guru membuat alat peraga sederhana.

Adapun proses pembuatan alat peraga berbasis limbah karet sandal yaitu:

1. Memotong bentuk sisa sandal menjadi lebih rapih sehingga mudah untuk dibentuk

2. Memotong sisa karet sandal sesuai dengan ketebalan yang diinginkan. Hal ini karena kondisi ketebalan pada sisa limbah memiliki ketebalan yang berbeda maka diperlukan alat untuk memotong ketebalan sisa limbah karet

3. Menentukan dan menyesuaikan pembuatan alat perga yang efektif 
sesuai dengan materi. Materi yang perlu memgunakan alat perga misalnya materi mengenai waktu maka akan dibuat alat perga matematika berupa jam dinding.

4. Membuat rangka jam dinding dari bahan yang mudah digunakan misalnya kayu bekas atau rangka besi yang mudah dan murah di dapatkan

5. Menggunakan sisa karet sandal untuk menutupi rangka yang sudah dibuat.

Kegiatan IbM bertujuan untuk membantu meningkatkan pengetahuan dan keterampilan guru sekolah dasar tentang pembuatan alat peraga matematika berbasis lingkungan, melatih pembuatan alat peraga matematika sekolah.

\section{METODE PELAKSANAAN KEGIATAN}

Langkah awal dalam metode yang akan dilakukan adalah sebagai beriku kegiatan pengabdian yaitu melakukan sosialisasi kepada mitra 1 dan mitra 2 mengenai langkah-langkah yang akan dilakukan dalam kegiatan pengabdian.

a. Penyuluhan dari Dinas Pendidikan

Kabupaten Cirebon dan UPT Pendidikan

Kecamatan Klangenan

Sosialisasi dan penyuluhan dilakukan oleh Dinas Pendidikan Kabupaten Cirebon dan UPT Pendidikan Kecamatan Klangenan tentang pentingnya menggunakan alat peraga pada mata pelajaran matematika yang dilaksanakan bulan Juli 2017. Mengingat materi matematika bersifat abstrak maka dengan berbantuan alat peraga, guru dapat memvisualisasikan materi menjadi sesuatu yang konkrit. Guru sebagai mitra diarahkan untuk membuat alat peraga berbasis limbah karet sandal dan hasilnya digunakan sesuai kebutuhan pada pembelajaran matematika. Guru juga diberikan arahan untuk mempatenkan karya mereka melalui lembaga HKI. Tujuan mempatenkan alat peraga berbasis limbah karet anorganik yaitu untuk melindungi hasil karya yang sudah dibuat oleh guru sebagai solusi dari masalah kesulitan dan mahalnya alat peraga matematika. b. Pelatihan dan Pendampingan Ketua LPPM dan TIM Dosen Universitas Muhammadiyah Cirebon

Solusi untuk masalah limbah karet yang belum dimanfaatkan sebagai alat peraga di sekolah yaitu diadakan pelatihan oleh tim IbM yaitu dosen Universitas Muhammadiyah sebagai akademisi dan adapula tambahan materi yang akan disampaikan oleh Ketua LPPM UMC. Tim dosen terdiri dari dosen PGSD dan dosen matematika. Dosen PGSD sebagai tim pelatih untuk memetakan materi matematika pada sekolah dasar sedangka dosen matematika sebagai pelatih pembuatan alat peraga matematika yang inovatif dan efektif. Sedangkan Ketua LPPM menjelaskan tentang proses benda atau hasil karya yang bisa di HKI kan termasuk alat peraga matematika berbahan baku limbah karet sandal yang unik dan memiliki nama yang unik pula. Benda atau karya yang dihasilkan haruslah baru, yang tidak pernah dibuat atau di HKI kan oleh orang lain. Pembuatan buku pedoman alat peraga matematika berbahan limbah karet sanda dapat di HKI kan apa bila memiliki ciri khas dan tidak pernah ditulis oleh siapapun. Adapun kegiatan pelatihan dan pendampingan adalah sebagai berikut:

\section{Pelatihan}

Sebagai contoh pelatihan yang akan diberikan dalam pembuatan alat peraga matematika adalah.

\section{Model alat peraga}

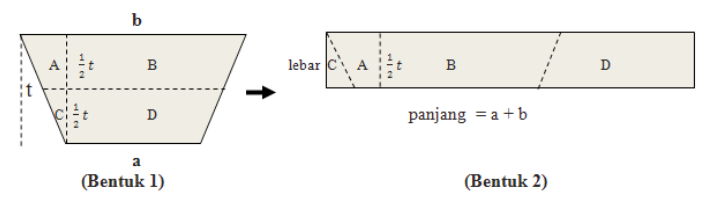

Gambar 1 model daerah trapesium dan daerah persegi panjang

a. Proses pembuatan

1) Bahan
a) Sisa limbah karet sendal
b) Lem karet
c) Papan triplek

2) Alat kerja

a) Pemotong limbah karet 
b) Pensil

c) Penggaris besi

d) Gunting/cutter

3) Langkah-langkah pembuatan

a) Potonglah ketebalan sisa karet sendal sesuai kebutuhan

b) Jika potongannya terlalu kecil sambungkan karet yang warnanya sama

c) Garislah yang rapih sehingga membentuk pola bangun datar trapesium

d) Guntinglah secara berlahan sampai terbentuk bangun datar

e) Sediakan triplek yang tidak terlalu tebal.

f) Tempelkan beberapa karet yang warnanya sama tetapi berbeda dengan warna dari bangun trapesium

g) Setelah bahan triplek yang dilapisi karet dan bangun trapesium telah jadi, potonglah bangun trapesium menjadi empat bagian sesuai gambar di bawah ini

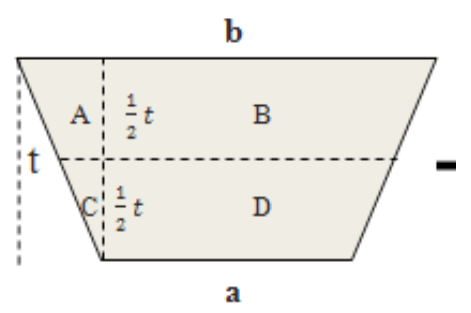

h) Bahan triplek tersebut dibuat pola gambar bangun datar persegi panjang

\section{Pendampingan}

Pendampingan dilakukan terhadap proses pembuatan alat peraga matematika oleh para guru mitra sampai dapat dikatakan berhasil dan sukses sampai memperoleh minimalnya 10 alat peraga dari kelas 1 sampai dengan kelas 6 sesuai dengan permasalahan yang ada. Selain itu pendampingan dilakukan pada saat penggunaan alat peraga dalam pembelajaran matematika di kelas, kususnya kelas rendah.

\section{HASIL PELAKSANAAN KEGIATAN}

Survei pendahuluan lokasi mitra 1 dan mitra 2 pada hari Kamis, tanggal 25 Mei 2017 bertujuan menganalisis situasi dan menganalisis kurikulum matematika dari kelas 1 sampai dengan kelas 6 mengenai materi yang dianggap siswa sukar untuk difahami dan memiliki nilai rata-rata di bawah KKM sehingga memerlukan alat peraga sebagai alat bantu memahami konsep materinya dan diharapkan nilai rata-rata siswa lebih baik. Kegiatan survei ini juga bertujuan untuk meminta izin melaksanakan kegiatan IbM kepada kepala sekolah agar kegiatan IbM berjalan dengan lancar dan dapat diikuti oleh semua guru khususnya guru matematika dengan baik. Berikut ini hasil dokumentasi hasil survei:

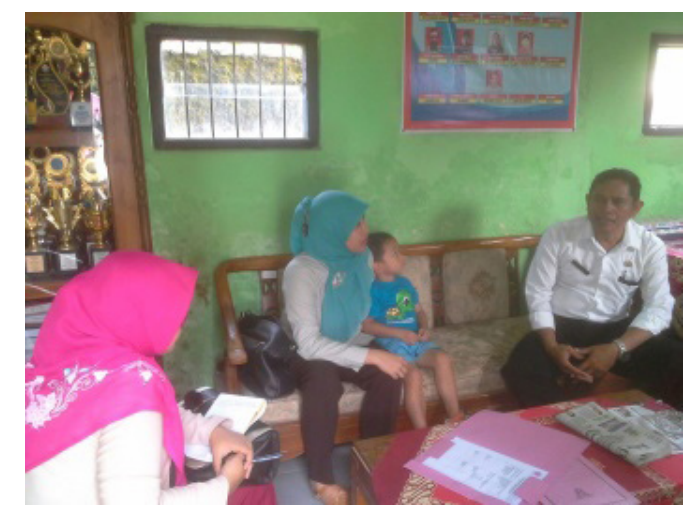

Gambar 2. Wawancara dengan kepala sekolah (Mitra)

Melaksanakan penyuluhan I pada hari Senin tanggal 10 Juli 2017 dengan pembicara Drs. H. Iman S, M.Pd dari Dinas Pendidikan Kabupaten Cirebon dengan peserta sebanyak 40 orang. Berdasarkan penjelasan Bapak Iman, mitra mendapatkan informasi mengenai pentingnya menggunakan alat peraga pada mata pelajaran matematika oleh karena itu guru harus dituntut profesional dalam mengajar, harus mengetahui sejauhmana siswa memahami penjelasan guru dalam mata pelajaran matematika, dan materi apa sajakah yang tidak dikuasai siswa dan harus dituntut menggunakan alat peraga sebagai alat bantu menyampaikan materi, karena mengingat materi matematika bersifat abstrak maka dengan berbantuan alat peraga, guru dapat 
memvisualisasikan materi menjadi sesuatu yang konkrit. Kegiatan ini dilaksanakan dengan melakukan metode ceramah dan metode tanya jawab. Mitra antusias untuk megikuti acara ini, karena informasi yang disampikan sangat sesuai dengan kebutuhan guru-guru sekolah dasar.

Menurut salah satu guru yang menjadi peserta, yaitu Ibu Muaijah mengatakan bahwa materi yang disampaikan sangat bermanfaat karena sesuai dengan kebutuhannya, sehingga dia lebih memahami manfaat dari penggunaan alat peraga di dalam kelas. Kegiatan tersebut dapat dilihat pada hasil dokumentasi di bawah ini:

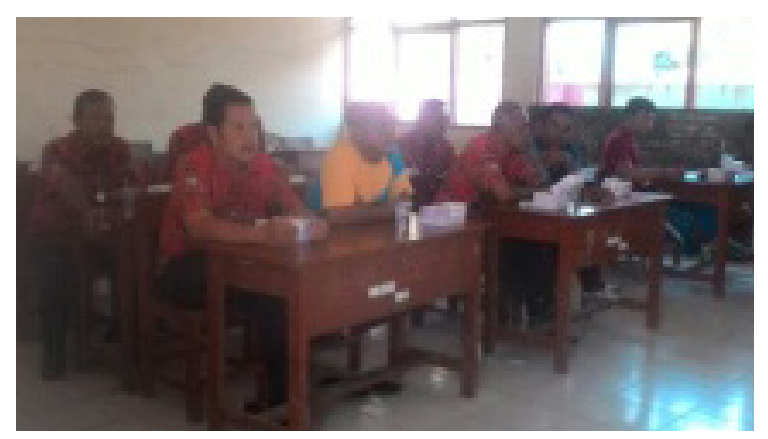

Gambar 3. Pelaksanaan sosialisasi dan penyuluhan I

Melaksanakan sosialisasi dan penyuluhan II pada hari Kamis tanggal 13 Juli 2017 dengan pembicara Bpk. H. Nurhadi, S.Pd dari UPT Pendidikan Kecamatan Klangenan tentang inovasi pembelajaran matematika di Sekolah Dasar. Berdasarkan penjelasan Bapak Nuradi, mitra mendapatkan informasi tentang konsep inovasi pembelajaran matematika di SD sehingga diharapkan guru termotivasi untuk melakukan perubahan dalam menyampaikan materi pada siswanya termasuk menyiapkan alat peraga yang inovatif untuk membantu siswa memahami materi yang disampaikan gurunya, khususnya materi dalam pelajaran matematika. Kegiatan ini dilaksanakan dengan melakukan metode ceramah dan metode tanya jawab. Mitra yang menjadi peserta yaitu Bapak Casnadi terlihat sangat antusias untuk mengikuti acara ini, karena materi yang disampaikan pembicara sangat sesuai dengan kebutuhan guru-guru yang profesional. Kegiatan tersebut dapat dilihat pada gambar 4:

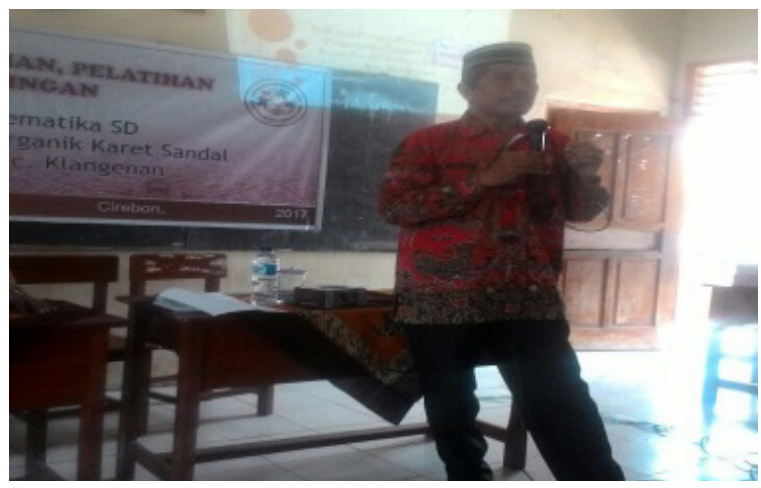

Gambar 4. Penyuluhan 2

Melaksanakan sosialisasi dan penyuluhan III dari Ketua LPPM UMC Dr. Badawi, S.E., M.Si pada hari Sabtu tanggal 15 Juli 2017 tentang produk yang dapat di HAKI-kan. Berdasarkan penjelasan pak Badawi, mitra mendapatkan informasi mengenai hak paten hasil karya yang di HAKI kan yaitu hasil karya yang inovatif, salah satunya yang dapat didaftarkan pada HAKI adalah alat peraga beserta buku panduan pembuatan alat peraga matematika. Kegiatan ini dilaksanakan dengan melakukan metode ceramah dan metode tanya jawab. Mitra menyimak penjelasan dengan baik, karena menurutnya informasi ini baru didapat pada acara ini. Kegiatan tersebut dapat dilihat pada hasil dokumentasi di bawah ini:

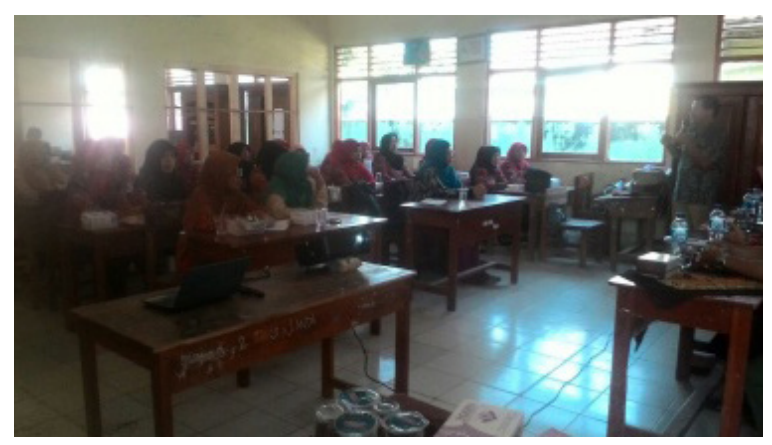

Gambar 5. Penyuluhan 3

Tim IbM dan 3 Mahasiswa membuat 10 desain alat peraga matematika berbahan baku sampah anorganik karet sandal sebagai contoh dalam melaksanakan pelatihan untuk 
guru-guru pada hari Senin-Rabu tanggal 17-19 Juli 2017. Mahasiswa antusias dalam membantu dosennya membuat desain alat peraga matematika, mahasiswa terdiri dari 3 orang yang berasal dari prodi matematika dan PGSD. Adapun hasil dokumentasi pembuatan alat peraga dapat dilihat di bawah ini:

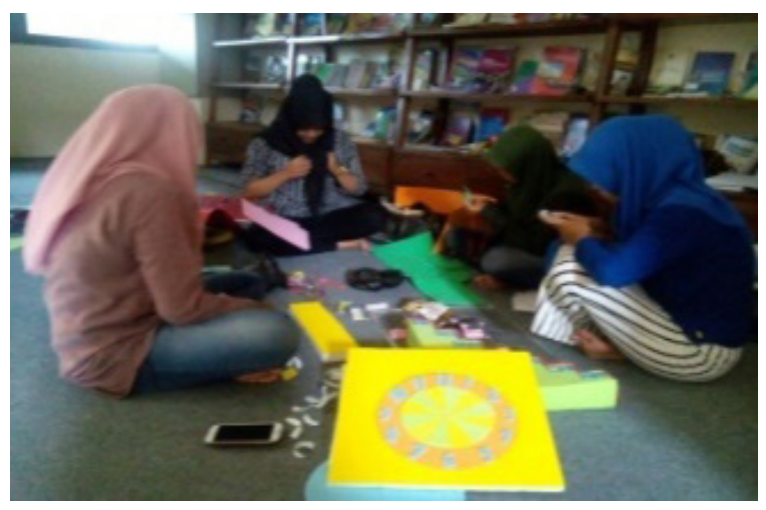

Gambar 6. Membuat desain alat peraga matematika

Melaksanakan sosialisasi dan penyuluhan IV tentang pengertian, macammacam, tujuan, manfaat dan cara membuat alat peraga berbahan baku sampah anorganik beserta cara menggunakan alat peraganya (karet sandal) pada hari Kamis tanggal 20 Juli 2017 dengan pembicara Dosen PGSD dan Dosen Prodi Matematika Universitas Muhammadiyah Cirebon (Tim Pelaksana IbM). Kegiatan ini dilaksanakan dengan melakukan metode ceramah dan metode tanya jawab. Mitra dengan jumlah 40 guru mengikuti kegiatan dengan antusias menyimak pembicara, karena informasi yang disampaikan menambah wawasan pengetahuannya tentang alat peraga, ternyata alat peraga dapat dibuat dengan limbah anorganik karet sandal, alat peraga tampak lebih menarik untuk dilihat dan terjangkau untuk didapat dan digunakan semua guru sekolah dasar. Kegiatan ini dapat dilihat dari hasil dokumentasi pada gambar 7:

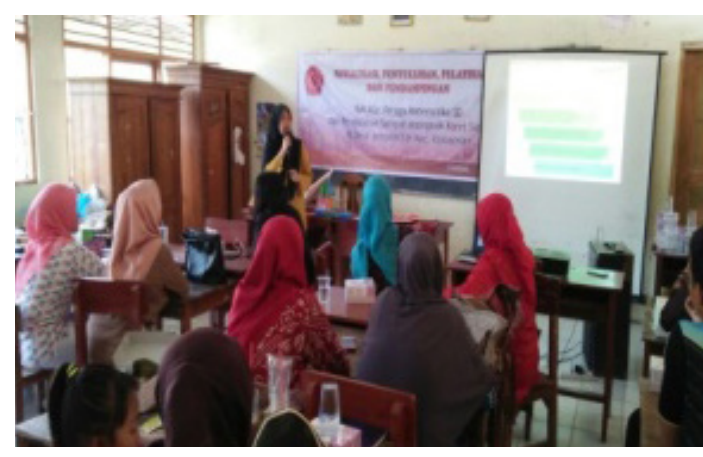

Gambar 7. Tim Pelaksana IbM memberikan penyuluhan

Melaksanakan pelatihan dan pendampingan I, II, dan III pembuatan alat peraga pada hari Jum'at tanggal 21 Juli 2017 sampai dengan tanggal 24 Juli 2017 Pelatihan ini, diawali dengan melakukan pemetaan materi matematika pada sekolah dasar, membuat kelompok dan membagikan bahan baku pembuatan alat peraga matematika. Kegiatan ini menggunakan metode ceramah, metode kelompok dan metode tanya jawab. Pembagian kelompok pada guru-guru berdasarkan kelas yang mereka pegang agar lebih memahami materimateri yang dianggap sukar difahami oleh siswanya dan membutuhkan alat peraga. Kegiatan pelatihan ini terlihat antusias. Menurut salah satu sumber dari peserta pelatihan yaitu guru kelas 4 , yang bernama Latifah. Ia mengatakan bahwa pelatihan ini termasuk kedalam pelatihan yang baru dilakukan oleh guru-guru di SDN 1 dan 2 Jemaras Lor, sehingga pelatihan ini dapat menambah wawasan tentang pembuatan alat peraga matematika yang ekonomis dengan memanfaatkan limbah karet sandal.

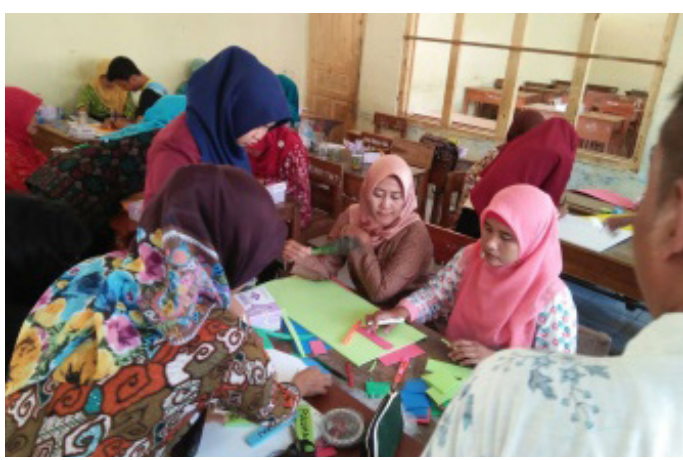

Gambar 8. Hasil karya guru-guru "alat peraga matematika" 
Mengadakan lomba kreasi alat peraga matematik berbahan baku sampah anorganik karet sandal beserta pedoman cara pembuatannya selama 4 hari dimulai pada hari Senin tanggal 24 Juli 2017 sampai hari Kamis tanggal 27 Juli 2017. Kegiatan ini dimaksudkan untuk memotivasi guru-guru dalam pembuatan alat peraga matematika berbahan sampah anorganik karet sandal yang inovatif

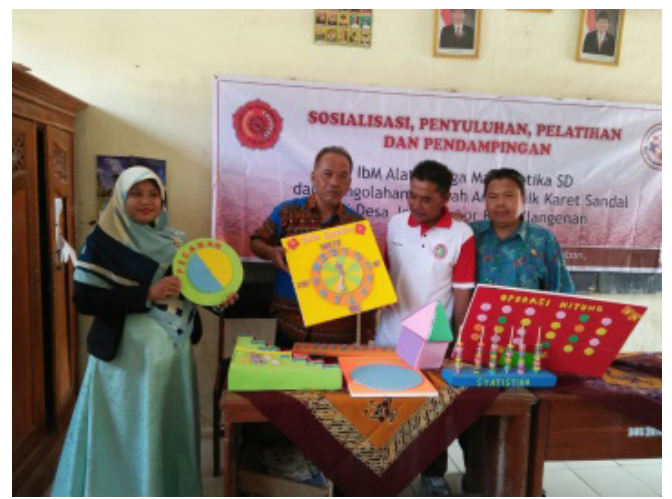

Gambar 9. Hasil karya alat peraga

Dari pelaksanaan lomba kreasi alat peraga matematika tersebut, menghasilkan 10 alat peraga matematika, yakni: (a) Pohon bilangan prima; (b) Jamur keliling bandar kadal (jam rumus keliling bangun datar karet sandal); (c) Garis bilbul karet (garis bilangan bulat dari karet); (d) Jam sudut; (e) Tabel pasang bilangan; (f) Tabel jenis sudut; (g) Menara hanoi karet sandal; (h) Membilang loncat; (i) Diagram pecahan; (j) Gambar jenis-jenis sudut

Alat peraga yang telah dibuat kemudian diimplementasikan pada proses pembelajaran di kelas agar dapat mengetahui keefektifan dari alat peraga tersebut, apakah alat peraga yang telah dibuat dapat membantu siswa memahami materi yang disampaikan gurunya atau tidak. Kegiatan ini dilakukan pada tanggal 2 Agustus 2017 dengan didampingi oleh tim pelaksana. Kegiatan proses pembelajaran di dalam kelas terlat lebih efektif dan siswa lebih bersemangat untuk mengikuti proses pembelajaran. Banyak siswa yang melakukan tanya jawab, mempraktikan sendiri penggunaan alat peraga, dan pada akhir mata pelajaran, guru membagikan soal dengan hasil jawaban siswa yang memuaskan, ada 3 orang yang nilainya masih di bawah KKM. Kegiatan tersebut dapat dilihat pada gambar di bawah ini:

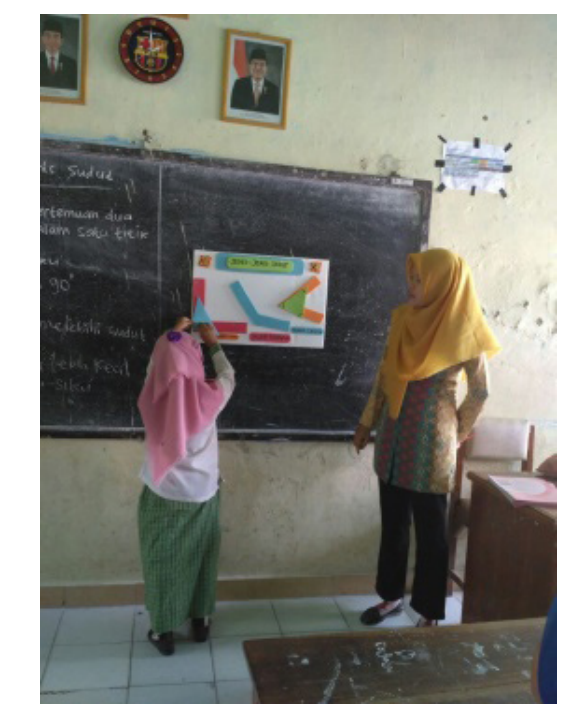

Gambar 10. Implementasi alat peraga matematika

Menyusun buku pedoman cara membuat alat peraga matematika yang berbahan baku sampah anorganik karet sandal. Buku pedoman cara membuat alat peraga sangat penting dibutuhkan oleh seorang guru untuk membuat sendiri alat peraganya, lebih ekonomis dibandingkan mereka membeli di toko. Dengan memperoleh buku panduan ini, guru lebih sering membuat dan kreatif (berkreasi) untuk membuat alat peraga matematika. Buku pedoman ini akan didaftarkan pemerolehan ISBN.

Memilih alat peraga yang inovatif dan unik, artinya belum ada yang membuat alat peraga tersebut. Dari 10 alat peraga yang telah di buat oleh guru-guru, ada satu alat peraga matematika yang terpilih berdasarkan kriteria keunikan, dan tim memberi nama alat peraga itu dengan nama "Jamur keliling bandar kadal (jam rumus keliling bangun datar karet sandal)". Setelah itu alat peraga tersebut akan di HKI-kan, dan saat ini masih dalam tahap pendaftaran HKI. Lebih lanjutnya dapat dilihat pada gambar di bawah ini: 


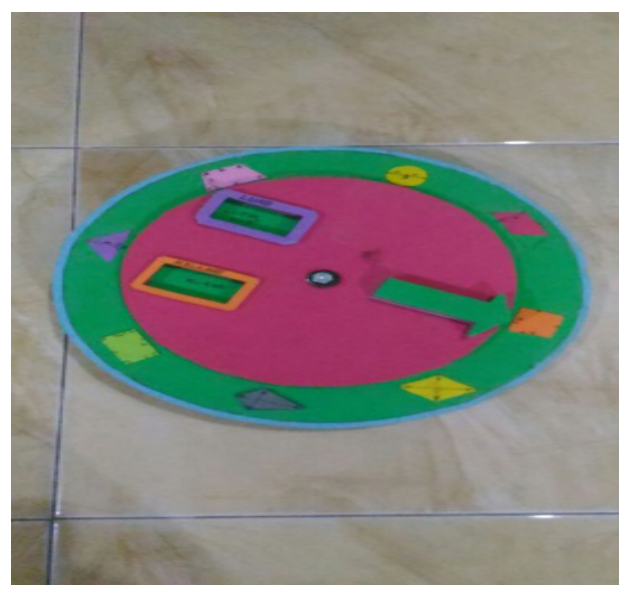

Gambar 11. Jamur keliling bandar kadal

\section{SIMPULAN DAN SARAN}

\section{Simpulan}

Kegiatan acara $\mathrm{IbM}$ alat peraga matematika SD dari pengolahan sampah karet sandal di Kecamatan Klangenan berjalan dengan lancar. Kegiatan ini dilakukan dari bulan Mei sampai dengan bulan Agustus 2017.

Kegiatan ini dimulai dari survai lokasi untuk meminta izin dan menganalisis permasalahan yang ada agar dapat memperoleh informasi alat peraga apa saja yang dibutuhkan sampai dengan menyusun buku pedoman cara membuat alat peraga berbahan baku karet sandal. Hasil dari kegiatan IbM adalah: (1) Guru mendapatkan ilmu tentang manfaat alat peraga dalam pembelajaran matematika dan cara membuat alat peraga; (2) Guru lebih kreatif karena telah menghasilkan 10 alat peraga matematika yang ekonomis yaitu (a) Pohon bilangan prima, (b) Jamur keliling bandar kadal (jam rumus keliling bangun datar karet sandal), (c) Garis bilbul karet (garis bilangan bulat dari karet), (d) Jam sudut, (e) Tabel pasang bilangan, (f) Tabel jenis sudut, (g) Menara hanoi karet sandal, (h) Membilang loncat, (i) Diagram pecahan, (j) Gambar jenis-jenis sudut ; (3) Siswa sekolah dasar menyenangi proses pembelajaran matematika dilihat dari hasil tes akhir yaitu rata-rata nilainya lebih dari 70; (4) Menghasilkan Draf pedoman cara membuat alat peraga berbahan baku limbah karet sandal.

\section{Saran}

Hasil kegiatan ini dapat diimplementasikan dalam acara workshop nasional untuk guru-guru sekolah dasar. Alat peraga matematika yang berbahan limbah karet sandal tergolong aman untuk digunakan pada proses pembelajaran di dalam kelas, dan dapat dikreasikan untuk media pembelajaran pada mata pelajaran apapun.

\section{PERSANTUNAN}

Terlaksananya kegiatan IbM ini tidak terlebas dari bantuan dan bimbingan beberapa pihak. Ucapan terima kasih kami sampaikan kepada Kemenristek Dikti melalui LPPM Universitas Muhammadiyah Cirebon yang telah memberikan dana sehingga kegiatan ini dapat berjalan dengan baik dan lancar.

\section{DAFTAR PUSTAKA}

Hadi, Sudharto P. (2005). Demensi Lingkungan Perencanaan Pembangunan. Yogyakarta: Gadjah Mada University Press.

Kementerian Lingkungan Hidup. (2008). Undang-Undang RI Nomor 18 Tahun 2008 tentang Pengelolaan Sampah. Jakarta.

Lembaga Penelitian dan Pengabdian Masyarakat. (2016). Universitas Muhammadiyah Cirebon.

Parwati, NN \& Putu Wisna, A. (2013). IbM Media Pembelajaran Matematika SD di Kecamatan Penebel. Laporan IbM tahun 2013. Jakarta: Ristekdikti.

Priatna D, dkk. (2007). Modul Pendidikan Matematika I. Bandung: Upi PGSD Kampus Cibiru. Suwangsih, E \& Tiurlina. (2006). Model Pembelajaran Matematika. Bandung: UPI PRESS. 
p ISSN: 1410-9344, e ISSN: 2549-5631

Suwardi, Masni Erika Firmiana, Rohayati. (2014). Pengaruh Penggunaan Alat Peraga Terhadap Hasil Pembelajaran Matematika pada Anak Usia Dini. Jurnal Al-Azhar Indonesia Seri Humaniora. Vo. 2 No. 4

Tim BPS Kabupaten Cirebon. 2015. Kabupaten Cirebon dalam Angka. Cirebon: BPS Kabupaten Cirebon. 